\title{
CANEZIN, M. T. Sindicato e magistério: constituição e crise. Goânia: Editora UFG, 2009.
}

\section{Por Juliana Subirá}

Os profissionais da educação possuem entidades representativas organizadas nas distintas esferas públicas, federal, estadual e municipal, que negociam reivindicações do magistério. Os sindicatos do magistério corporificam a luta dos professores por melhores condições de trabalho e remuneração, para além da valorização da classe. Na obra "Sindicato e magistério: constituição e crise", Canezin nos convida a percorrer o processo da construção histórica do sujeito coletivo, o sindicato, mostrando a dinâmica externa e interna dos idos de 1979-1989, dessa voz política que representa os professores no estado de Goiás.

$\mathrm{Na}$ apresentação desta obra, a professora Ana Lúcia da Silva, de Goiânia, destaca a importância de tomarmos ciência do processo histórico, de como um setor da classe trabalhadora transformou-se em sujeito histórico e a indaga sobre o seu silenciamento na atualidade.

O primeiro capítulo é dedicado às definições acerca de classes sociais e como esses sujeitos, em processo de constituição por meio dos movimentos sociais, se estruturam no trabalho e na sociedade. Nesse contexto, analisa como se enquadra a relação do professor - prestador de serviço público como trabalhador, no aparato estatal com seu empregador, o Estado.

A obra, no segundo capítulo percorre a construção histórica, política e social do período que antecede a década de 1970 até década de 1980, ao analisar como se como se constitui a sociedade goiana; as condições de trabalho; o fluxo migratório para zona urbana; como o aparato estadual expressou um locus privilegiado do clientelismo; e o cenário da elaboração do Estatuto do Magistério.

O terceiro capítulo explicita os bastidores das mobilizações dos professores da rede pública de Goiás na conjuntura de 1979 - 1982 por reivindicações de melhores condições de trabalho e salários ao sujeito coletivo - classe dos professores.

Os capítulos quarto e quinto mostram o cenário político de governo de Iris Rezende e, posteriormente, de Santillo, nos entraves com as mobilizações do CPG e de seus encaminhamentos frente às reivindicações. Cabe ressaltar a aprovação do Estatuto do Magistério Público Estadual (1984) e a constituição do Plano de Cargos e Salários, pois este último revoga o Estatuto do Magistério e cria um único Estatuto do Servidor Público, mostrando um retrocesso às especificidades das reivindicações expressas no Estatuto do Magistério Público. O último capítulo expressa a lógica interna do movimento do CPG delineando as divergências políticoideológicas.

A autora encontra em Offe referêncial classificatório, que repensa a profissão do professor da rede pública e explica o que significa seu "trabalho em serviços", uma vez que, este último tem diferenciação estrutural da força de trabalho e repercussão tanto nas teorias científicas quanto no conflito social.

As especificidades do trabalho em serviços públicosimpactam diretamentena determinação dos salários e na natureza dos conflitos, 
expressos, por vezes, em reivindicações. Segundo Offe as formas de gratificação e remuneração dos que fazem prestação de serviços públicos (1991, apud CANEZIN, 2009, p. 27) "com o devido cuidado podem ser caracterizadas como salário político, na medida em que representam formas, principalmente normativas e simbólicas de remuneração". Os salários na estrutura estatal são definidos de acordo com o grau de importância ao aparato administrativo governamental, motivo este ser o alvo, tanto na esfera nacional quanto estadual, das movimentações dos professores da rede pública de Goiás.

Ao analisar a sociedade goiana, a autora apresenta as características que impactam diretamente nas movimentações geradas pelos professores e sua prática sindical. Dentre estas destaca: alterações na estrutura produtiva da economia; urbanização acelerada; ampliação das funções do setor público, resultando na expansão da máquina governamental; aumento de empregados no setor público estatal; altas taxas de inflação e baixos índices de emprego. O inchaço no setor público dos empregados precarizou a situação de pagamento dos salários, ocorrendo, por vezes, atraso no pagamento dos salários dos professores da rede pública, e consequente nas manifestações de greves.

Neste contexto social que surge um dos primeiros propulsores da relação sindicato e magistério, o Estatuto do Magistério. Aprovado no ano de 1978, apontava critérios para a fixação de vencimentos, gratificações, qualificação e regência de classe, mas não contemplava questões acerca do provimento de vagas para professores e diretores e forma de ingresso. Neste mesmo ano, os professores tomam a iniciativa de se reunirem em assembleias para discutirem questões sobre as condições de funcionamento das escolas, o exercício profissional e a atuação da entidade CPG, que ainda não favoreciam a organização coletiva e que funcionava como uma extensão do governo até o presente momento. As assembleias resultaram na elaboração da pauta de reivindicações. Ideias
Destacavam-se, pois, na pauta além da reivindicação salarial, a regularização dos direitos trabalhista, o concurso público e a valorização do professor habilitado, bem como a escolha dos diretores através de eleição (CANEZIN, 2009, p. 88).

Em 1979, quando começa uma eclosão de greves por todo o país, inicia-se o movimento dos professores da rede pública deflagrando a primeira greve no estado de Goiás, com grandes repercussões na sociedade. O CPG já com pauta de reivindicações elaborada nas assembleias lutava principalmente contra o clientelismo político da Secretaria da Educação do Estado.

As mobilizações foram intensas no período de 1979-1982, na gestão do governador Ary Valadão, que, ao tentar dissuadir o movimento, afirmou concordar com a veracidade das reivindicações, mas ao deparar-se com as impossibilidades orçamentárias não pode cumpri-las. $\mathrm{Na}$ transição de governo a expectativa de mudanças por promessas das campanhas eleitorais em atender as reivindicações houve um refluxo no movimento, porém durante o período de 1983-1986, no governo de Iris Rezende, incidiram inúmeros confrontos com a categoria que cobrava as promessas do discurso da campanha eleitoral. No período pesquisado por Canezin, foi na gestão de Santillo, de 1987-1990, que ocorreram mais ações prejudiciais ao magistério com medidas da suspensão do gatilho salarial da gestão anterior, fim do piso salarial e a formulação de único estatuto do servidor público.

A autora nos mostra que no percurso das ações do movimento dos professores com os diferentes governos, a entidade sindical foi além da contestação puramente sindical (condições de trabalho e salário), ao tematizar a exigência de formulação de novas formas de atuação pertinentes à área da educação.

A greve foi sinalizada por Canezin como principal instrumento de mobilização, organização e representatividade do sujeito coletivo, instituindo-se no espaço do poder como voz dos professores, com capacidade de reivindicar as condições materiais e não 
materiais que haviam sido negadas pelo Estado.

Durante a década de 1980 a prática sindical dos professores, como uma categoria particular de servidores públicos, conseguiu atingir níveis diferenciados de mobilização, de organização e percepção do significado do retirar real social e sindical, participando até na criação de novas formas de representação da classe, entre elas a CUT e o PT. As reflexões da entidade e da autora, porém, evidenciam que ao distanciar-se das questões específicas do trabalho escolar, não se conseguiu despertar na categoria o sentimento de pertencimento a uma classe. Este é o desafio localizado na entidade, o de articular lógica interna e externa da prática sindical.
Parte das reivindicações apontadas desde 1979, nas assembleias dos professores de Goiás, ainda permeiam o cenário atual social e político dos professores da rede pública, como as reivindicações salariais na luta pela implantação do Piso Salarial Profissional Nacional, já aprovada em lei desde 2008, e a valorização do professor habilitado.

Pelo minucioso exercício da autora de evidenciar a trajetória da constituição do sindicato e do magistério, as resistências, as reivindicações e as conquistas. Esta obra é recomendada aos pesquisadores e profissionais da área da educação, especialmente os que lutam pela valorização e dignidade dos professores como sujeito coletivo. 